UDC: $577.3+615.9$

\title{
QUERCETIN AND HISTAMINE EFFECTS ON FREE RADICAL REACTIONS IN RAT ERYTHROCYTES
}

\author{
N. P. HARASYM ${ }^{凶}$, M. Y. BOOKLYV, A. R. ZYN, S. M. MANDZYNETS, \\ A. O. BEZKOROVAINY, D. I. SANAHURSKY \\ Ivan Franko National University of Lviv, Faculty of Biology, \\ Departments of Biophysics and Bioinformatics, Ukraine; \\ 凶e-mail: garasymnataly@gmail.com
}

Received: 12 June 2020; Accepted: 17 December 2020

The effects of quercetin and histamine separately or in combination on the free radical state of rat erythrocytes were estimated in vitro. Quercetin $(0.1 ; 0.5 ; 3.0 ; 5.0 \mathrm{mM})$ or histamine $(0.01 ; 10.0 \mu \mathrm{M})$ were added to whole blood separately or in combination. The content of hydroperoxides, TBA-active products and carbonyl groups of proteins in erythrocytes after hemolysis was determined. The greatest influence of quercetin and histamine on erythrocytes state indicators was revealed under their combined action, when the level of TBA-active products and the content of carbonyl groups of proteins were found to be increased substantially.

Ke ywords: histamine, quercetin, erythrocytes, lipid peroxidation, proteins carbonyl groups.

A ctivation of lipid peroxidation is one of the triggering mechanisms of stress damage with the disorder of cellular metabolism, which is primarily associated with the damaged cellular and subcellular membranes. There is an antioxidant defense system in the body to neutralize excess lipid peroxidation and maintain a steady intracellular concentration of free radicals and lipoperoxidum [1]. The unregulated oxidative modification of lipids, proteins, and nucleic acids induced by multiple oxidants has been implicated in the pathogenesis of many diseases [2, 3].

Quercetin activates $\mathrm{Na}^{+}-\mathrm{K}^{+}-2 \mathrm{Cl}^{-}$cotransporter 1, leading to elevation of the cytosolic $\mathrm{Cl}^{-}$concentration, which down-regulates gene expression of epithelial $\mathrm{Na}^{+}$channel. As a result of the aforementioned actions, polyphenols show various beneficial effects on body functions including regulation of blood pressure via diminution of vascular contraction and renal $\mathrm{Na}^{+}$reabsorption by influencing epithelial $\mathrm{Na}^{+}$channels gene expression and $\mathrm{Na}^{+}, \mathrm{K}^{+}$-ATPase activity [4]. Quercetin is an antioxidant that effectively regulates energetic metabolism in the myocardium, reduces its requirement in oxygen, stabilizes the cytoplasmic membrane, and causes anti-arrhythmic and anabolic effects. The drug is able to reduce the concentration of free radicals and toxic peroxidation products [1]. Quercetin has been reported to reduce the amount of histamine in the blood. However, the mechanism of reducing the amount of histamine in the blood is unknown. Quercetin absorbs free radicals and has protective effects against oxidative stress-mediated neuronal damage [5]. Published adequate scientific data for safety assessment in regard to the long-term use ( $>12$ weeks) of high supplemental quercetin doses $(\geq 1000 \mathrm{mg})$ are currently not available. Based on animal studies involving oral quercetin application some possible critical safety aspects could be identified such as the potential of quercetin to enhance nephrotoxic effects in the pre-damaged kidney or to promote tumor development, especially in estrogen-dependent cancer. Furthermore, animal and human studies with single time or short-term supplemental quercetin application revealed interactions between quercetin and certain drugs leading to altered drug bioavailability [6]. Quercetin reduced significantly erythrocytes lipid peroxidation levels and the susceptibility to hemolysis induced by the free radical generator AAPH. Chronic quercetin supplementation has antioxidant potential before and

(C) 2021 Harasym N. P. et al. This is an open-access article distributed under the terms of the Creative Commons Attribution License, which permits unrestricted use, distribution, and reproduction in any medium, provided the original author and source are credited. 
after a strenuous eccentric exercise thus making the erythrocytes capable of better cope with an oxidative insult [7]. The effect of quercetin on free radical processes against the background of allergic reactions, where histamine has the leading effect, remains unknown.

The seminal work on histamine was published in 1910, but histamine was not identified as a mediator of anaphylactic reactions until 1932. Research later showed that histamine is a major mediator responsible for the symptoms of allergic rhinitis, with its activities mediated through $4 \mathrm{G}$ proteincoupled receptors. Most of histamine's effects are exerted through the $\mathrm{H}_{1}$ receptor, but some effects are through the $\mathrm{H}_{2}$ and $\mathrm{H}_{3}$ receptors, and possibly also through the $\mathrm{H}_{4}$ receptor $[8,9]$. There are reports that erythrocytes contain histamine receptors, but they do not know exactly what function they play [10]. It is known that histamine regulates the release of reactive oxygen species by blood neutrophils. Thus, histamine is associated with free radical processes in the body. There are reports that histamine challenge reduces magnesium levels in erythrocytes while plasma levels remain unchanged. This histamine-induced decrease in magnesium levels occurs regardless of the diagnosis of asthma, and it is not correlated with the degree of bronchial hyperreactivity [11].

Among blood cells, erythrocytes remain the least studied in terms of allergic reactions, where the leading role is played by histamine. The effect of quercetin on free radical processes in erythrocytes also remains unknown. It is known that erythrocytes are important components of the blood that perform important functions to maintain homeostasis (transport gases, perform a protective function, etc.). One mechanism through which oxygen tension and therefore RBCs affect vascular function is the contractile force of smooth muscle cells. Chang and Detar reported that a reduction in oxygen pressure led to reduced contractile tension of helical strips cut from the aorta, femoral arteries, and small arteries from skeletal muscle. Additionally, Taggart et al saw a decrease in smooth muscle force in hypoxia indicating smooth muscle response to oxygen may be independent of factors from the endothelium. Potential mechanics of smooth muscle response to oxygen tension are increased ATP-sensitive $\mathrm{K}^{+}$efflux or decreased voltage-sensitive $\mathrm{Ca}^{2+}$ influx. Alternatively, low oxygen tension affects the endothelial production of nitric oxide (NO) by eNOS, which requires oxygen as a substrate along with L-arginine. Many researchers have shown diminished relaxation by endothelial cells under low oxygen tension. Specifically, the apparent $K_{\mathrm{m}}$ of eNOS for $\mathrm{O}_{2}$ is $4 \mu \mathrm{M}$ and NOS activity begins to slow down once oxygen tensions start falling below $1 \%$ ( 7.6 torr or $10 \mu \mathrm{M})$. In summary, through the management of oxygen delivery RBCs effect eNOS function and smooth muscle contractility [12]. As quercetin can reduce the amount of histamine in the blood, it is important to study the combined effect of these substances on erythrocytes, in particular on their free radical state, which is a universal process of membrane destruction. The intensity of free radical processes reflects the degradation of erythrocytes. Therefore, such studies will expand knowledge about the safe usage of quercetin in patients with allergic reactions.

Objective. To study the effect of quercetin and histamine on the intensity of lipid peroxidation and oxidative protein modification in rat erythrocytes.

\section{Materials and Methods}

The nonlinear white rats-males body weighing 180-220 g were used for the experimental studies. (Rattus norvegicus f. Domesticus). Chloroform was used for euthanasia. Animals were treated in accordance with the requirements of the European Convention for the Conservation of Vertebrate Animals Used for Experimental and Scientific Purposes (Strasbourg, France 1986) and in accordance with the General Principles of Animal Work approved by the First National Congress on Bioethics (Kyiv, Ukraine, 2001). After decapitation of the animals, blood was collected in a glossy cup with heparin. An adequate amount of quercetin solutions were added to whole blood to a final concentration of $0.1 ; 0.3$; $0.5 ; 1 ; 3 ; 5 \mathrm{mM}$. Concentrations of 1 and $3 \mathrm{mM}$ are therapeutic and used in pharmacy (single dose for oral administration). The quercetin (brand PFA) was dissolved in warm saline at $37^{\circ} \mathrm{C}$ (oral use of quercetin dissolved in warm water used in medicine). In other experiments, a histamine solution $(0.01 \%$ histamine dihydrochloride solution used as a stock solution; manufacturer - Limited Liability Company "Immunolog", Ukraine, Vinnytsya) added to the blood to final concentration $0.01 ; 0.1 ; 1 ; 10 \mu \mathrm{M} .0 .9 \%$ $\mathrm{NaCl}$ used to prepare the solutions. In the series of experiments, histamine (minimum and maximum test concentrations: 0.01 and $10 \mu \mathrm{M}$ ) and quercetin (at a concentration of $0.1 ; 0.5 ; 3 ; 5 \mathrm{mM}$ ) added to the blood in various possible combinations. Quercetin 
concentrations for this chosen as follows: minimum and maximum concentrations; where $0.5 ; 3 \mathrm{~mm}$ are those concentrations that did not change the content of lipid hydroperoxides in plasma of blood in our previous in vitro experiments. Blood erythrocytes of 5 rats $(n=5)$ were used in each experimental group. The blood of intact animals and the blood to which saline was added were used as controls. They were incubated $5 \mathrm{~min}$, then centrifuged at 3000 rotation for $10 \mathrm{~min}$. Selected for analysis erythrocytes were laundered. The water was used for their hemolysis (1 part of erythrocytes and 5 parts of water). The content of hydroperoxides, TBA-active products, and carbonyl groups of protein were determined (aldehyde and ketone derivatives of neutral and basic character measured on the spectrophotometer ULAB102UV (China) at 370 and $430 \mathrm{~nm}$, respectively) in the selected samples [13-15]. The intensity of the oxidative modification of proteins was determined by the method of O. Yu. Dubinina in the modification of E. F. Meschyshen [15]. Protein content was determined by Lowry [16].

In vitro experiments can not reflect the whole chain of effects of quercetin and histamine on all biochemical interactions of the body, in particular, on erythrocytes, but they give a comprehensive response to the effects of these substances directly on the state of the studied indicators (namely the state of free radical processes).

Analyses of all data were conducted in Excel-10 for Windows. The values of parameters are given as mean $(M) \pm$ standard error $(m)$ and the degree of probability of difference $(P)$ between indicators where appropriate. The significance of the changes of variables with abnormal distribution by Friedman test was performed. A Student's $t$-test was performed to determine the statistical significance. Significance was considered to be a difference in the confidence index $P \geq 0.95 ; P \geq 0.99 ; P \geq 0.999$.

\section{Results and Discussion}

As we found that the saline addition to the blood caused a significant increase in the content of lipid hydroperoxides in the erythrocytes of rats $(7.8$ times, $P \geq 0,999)$. Therefore, all the study groups we had compared to the group were saline was added to the blood. Quercetin caused a decrease in the content of primary lipid peroxidation products in rat hemolysates. Moreover, the most pronounced decrease in the content of lipoperoxidation products by $84 \%, 88 \%, 88 \%$ were found at $0.3 ; 0.5 ; 1 \mathrm{mM}$ concentrations, respectively (Fig. 1). This indicates a slow down intensity of free radical reactions in erythrocytes. Added histamine at 0.01 and $10 \mu \mathrm{M}$ concentrations to whole blood reduced the content of the lipid hydroperoxides in erythrocytes by $36 \%$ and $38 \%$, respectively (Fig. 1). Simultaneous incubation blood in a medium with quercetin at $0.1 \mathrm{mM}$ concentration, and histamine with both $10 \mu \mathrm{M}$ and of $0.01 \mu \mathrm{M}$ concentration, caused a significant increase in the content of the lipid hydroperoxides in erythrocytes by 190 and 177\%, respectively (Fig. 1). A slightly increased content of these products was detected by the action of quercetin and histamine in a combination at $0.5 \mathrm{mM}$ and $0.01 \mu \mathrm{M}$ concentrations, respectively. The content of primary lipoperoxidation products decreased by $42 \%$ after simultaneous addition quercetin at the highest tested concentration and histamine at the lowest concentration to the blood. Quercetin at from 0.1 to $5 \mathrm{mM}$ concentrations on the background action of histamine at $0.01 \mu \mathrm{M}$ concentration caused a dose-dependent accumulation of lipid hydroperoxides in erythrocytes (Fig. 1).

Adding saline with diluted quercetin to the blood (in vitro) caused to decrease in the content of TBA-active products by 2.4 times $(P \geq 0.99)$. Therefore, the experimental samples compared with groups where red blood cells were in the medium with saline. The secondary products of lipid peroxide oxidation by the action of quercetin increased at $0.3 \mathrm{mM}$ concentration - 107\%, $0.5 \mathrm{mM}-152 \%$, $3 \mathrm{mM}-70 \%$. The content of TBK-active products was reduced by $39 \%$ by the influence of quercetin at the maximum tested concentration (5 mM) (Fig. 2). Histamine at 0.1 and $1 \mu \mathrm{M}$ concentration led to a decrease in the content of TBK-active products in rat erythrocytes by 39 and $41 \%$, respectively. Biogenic amine at the lowest and highest concentrations didn't cause significant changes in the content of secondary lipoperoxidation products. The content of TBK-active products increased by the action combination of histamine at $10 \mu \mathrm{M}$ concentration and quercetin. The maximum increase of content (by 211\%) was detected by action the combination of histamine $(10 \mu \mathrm{M})$ and quercetin at $5 \mathrm{mM}$ concentration (Fig. 2). The combination histamine at $0.01 \mu \mathrm{M}$ a concentration and quercetin at 0.1 and $0.5 \mathrm{mM}$ concentrations didn't change the intensity of the processes of lipid oxide oxidation. The content of TBK-active products in rat erythrocytes (20 and 26\%) was slightly reduced by the action simultaneous adding of histamine $(0.01 \mu \mathrm{M})$ and quercetin higher concentrations 


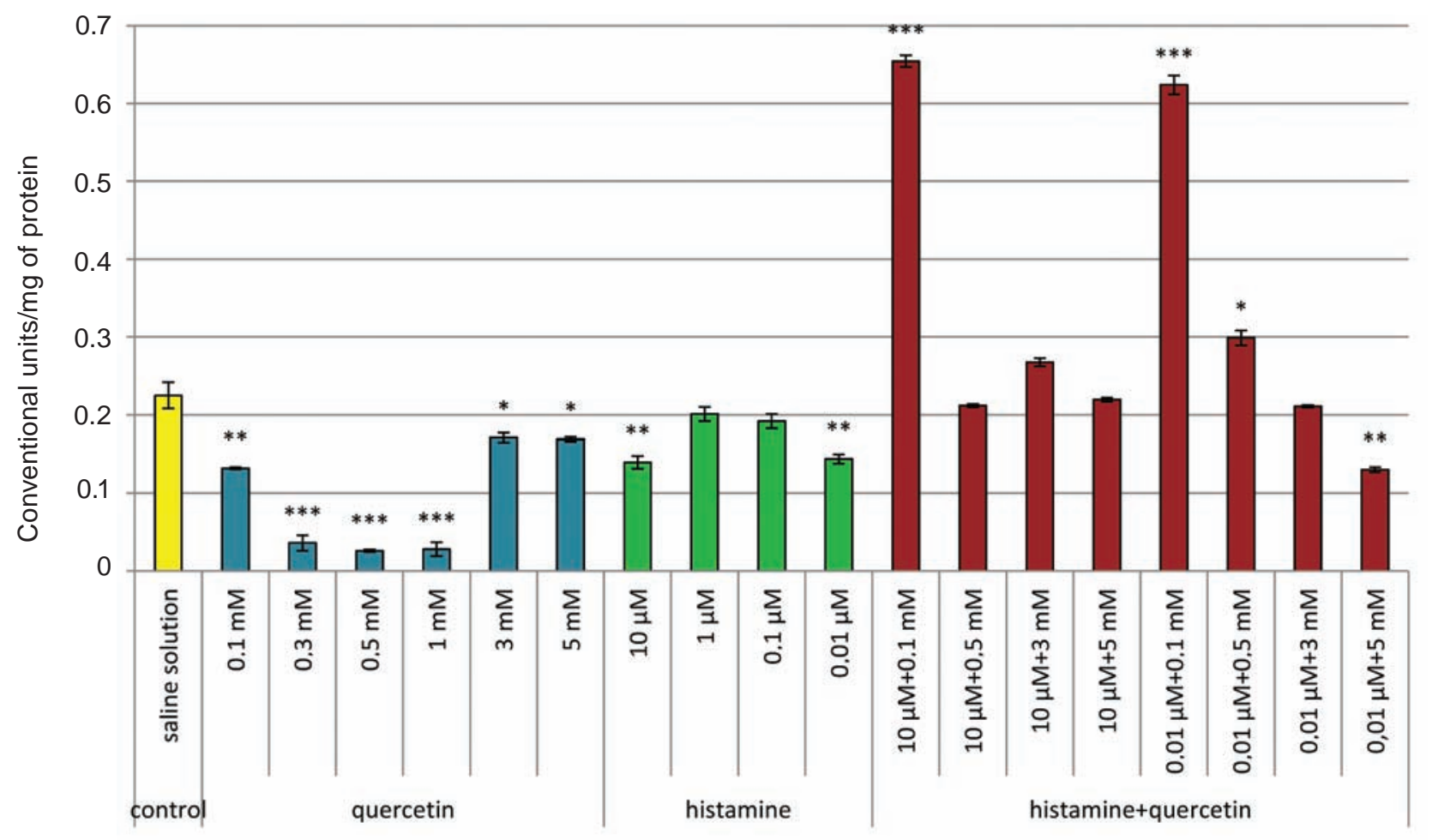

Fig. 1. The content of the hydroperoxides in rat erythrocyte haemolysates by the action of quercetin, histamine and the combination of histamine and quercetin (*P $\geq 0.95 ; * * P \geq 0.99 ; * * * P \geq 0.999$ )

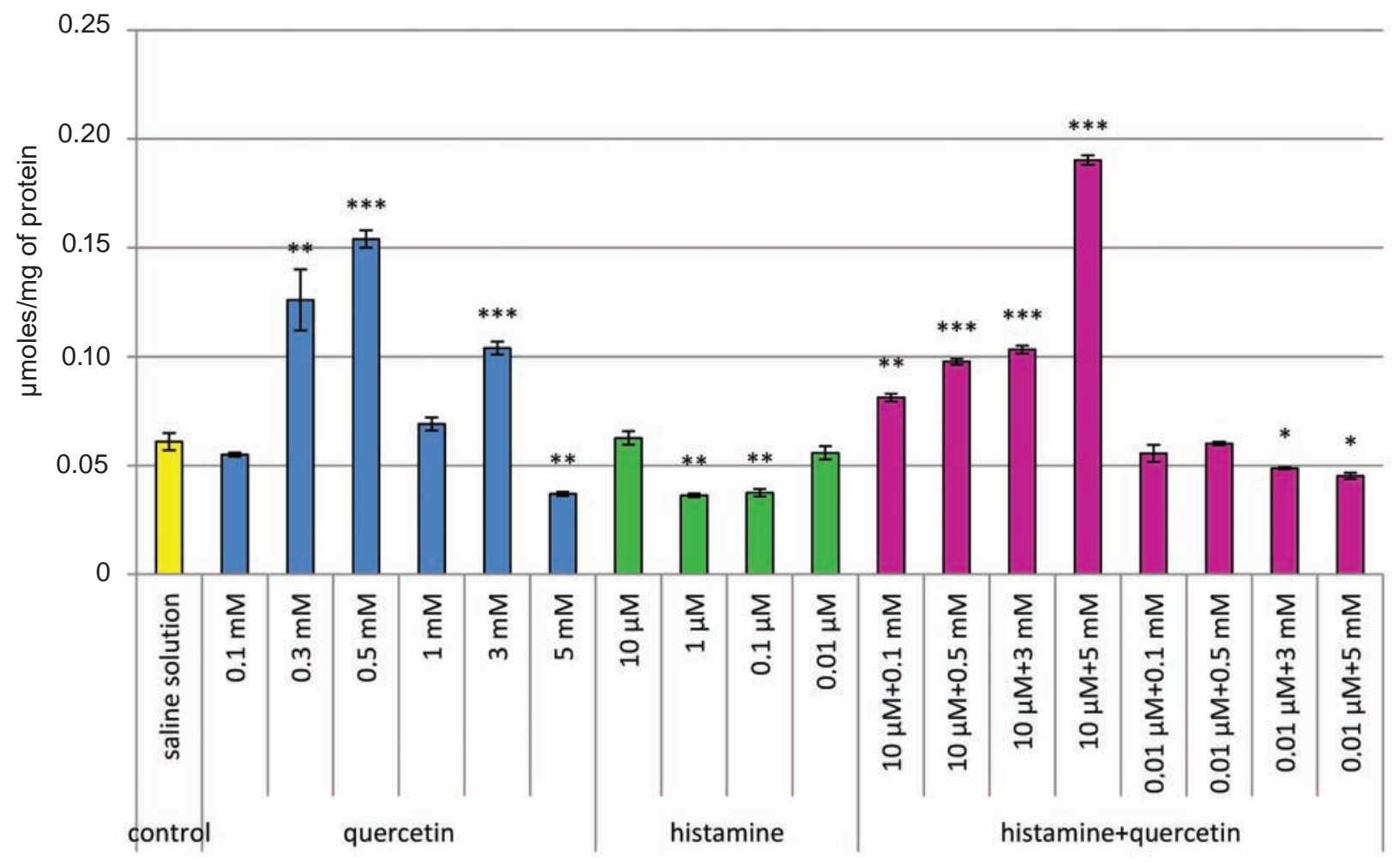

Fig. 2. The content of the TBA-active products in rat erythrocyte haemolysates under the action of quercetin, histamine and the combination of histamine and quercetin ( $\left.{ }^{*} P \geq 0.95 ; * * P \geq 0.99 ; * * * P \geq 0.999\right)$ 
(3 and $5 \mathrm{mM}$ ). Therefore, analyzing our results as a whole, we can conclude that quercetin causes a decrease in the content of primary lipoperoxidation products by increasing the secondary products. However, quercetin at a concentration of $5 \mathrm{mM}$ can suppress the intensity of lipid peroxidation processes as evidenced by the content of lipid hydroperoxides and TBA-active products. Intensification of lipid peroxidation processes indicates damage of erythrocyte membranes by quercetin (at $0.3 ; 0.5 ; 3 \mathrm{mM}$ concentration). As known from the literature, orally administrated of quercetin can be found at low concentrations in plasma metabolites, but it is not enough to show significant antioxidant activity. In plasma, quercetin and its metabolites are related mainly to albumin. Consumption of quercetin-rich foods does not increase the antioxidant activity of the plasma albumin fraction. At the same time, as known, a diet rich with quercetin is a protective factor against atherosclerosis. These results suggest that the quercetin metabolites do not show their antioxidant activity in plasma. But they are selectively accumulated in a specific target in the area of the vascular wall. However, there are other results from in vitro studies showing that quercetin is an effective antioxidant against lipid oxidation [17]. Probably quercetin at the tested concentrations, except the maximum (5 mM), binds to blood albumin and does not cause an antiradical effect on the erythrocytes of rats and leads to a violation of prooxidant-antioxidant homeostasis.

Histamine slows down the intensity of lipid peroxidation processes in rat erythrocytes. Thus, the content of lipid hydroperoxides decreased by the action of the biogenic amine at the maximum and minimum concentrations. And amine led to a decrease in the content of the TBA-active products at the mean concentration. The intensity of lipoperoxidation processes lower than the norm can be regarded as a negative phenomenon, and in these conditions, the membranes of erythrocytes may become stiffer, which will affect the passage of them through thin capillaries [18].

In general, the combination of histamine and quercetin caused an increase in the intensity of lipid peroxidation processes, except the next combinations of concentrations: $0.01 \mu \mathrm{M}$ histamine with 3 or $5 \mathrm{mM}$ quercetin, that caused a decrease in the content of lipoperoxidation products. Such a decrease in the intensity of lipid peroxidation may be due to the interception of free radicals by high concentrations of quercetin. Increasing the content of both lipid hydroperoxides and TBA-active products occurs with the simultaneous action of histamine at $10 \mu \mathrm{M}$ concentration and quercetin at $0.1 \mathrm{mM}$ concentration. Thus, histamine, in high concentration, caused the formation of free radicals, but the amount of quercetin was insufficient to inactivate those radicals.

We assume that quercetin and histamine change the intensity of lipid peroxidation processes in rat erythrocytes.

We found that the content of carbonyl groups of proteins of a neutral character significantly decreased by the saline solution was added to the blood $(P \geq 0.999)$. Therefore, all studying groups we compared to the group where we added saline to the blood. The content of carbonyl groups of proteins of neutral character increased by $354 \%$ by the action of quercetin $(0.5 \mathrm{mM})$. However, quercetin of lower concentrations ( 0.1 and $0.3 \mathrm{mM}$ ) slightly reduces the intensity of oxidative modification of proteins (by 10 and $26 \%$, respectively). In erythrocyte hemolysates, the content of carbonyl groups of proteins (neutral character) was reduced by more than $53 \%$ by the action of quercetin (the maximum of tested concentration). Noticed that the content of carbonyl groups of proteins of a neutral nature didn't change by the action of quercetin at therapeutic 1 and $3 \mathrm{mM}$ concentrations (Fig. 3). That confirmed the positive effect of such doses of the drug on the protein structures of erythrocytes. Quercetin is known to affect enzymatic systems and metabolic processes [19]. Therefore, these changes explained precisely by the influence on the oxidative modification of the protein structure, which we have proved. Clinico-pharmacological properties of quercetin are associated with versatile anti-inflammatory effects: membrane stabilizing, antileukotriene, antioxidant [20]. Thus, the decrease in the intensity of oxidative modification of proteins is associated with the antioxidant effect of quercetin.

The content of carbonyl groups of proteins of a neutral character only increased at lower concentrations $(0.1 \mu \mathrm{M}$ by $273 \% ; 0.01 \mu \mathrm{M}$ by $209 \%)$ after added histamine to whole blood. Histamine at high concentrations ( 1 and $10 \mu \mathrm{M})$ didn't alter the intensity of oxidative protein modification in rat erythrocytes. (Fig. 3). It found that incubation of blood in the medium with quercetin and histamine in all studied combinations of concentrations caused a significant increase in the content of carbonyl groups of neutral character in the erythrocytes of rats (Fig. 3). We found that histamine at a lower concentration 


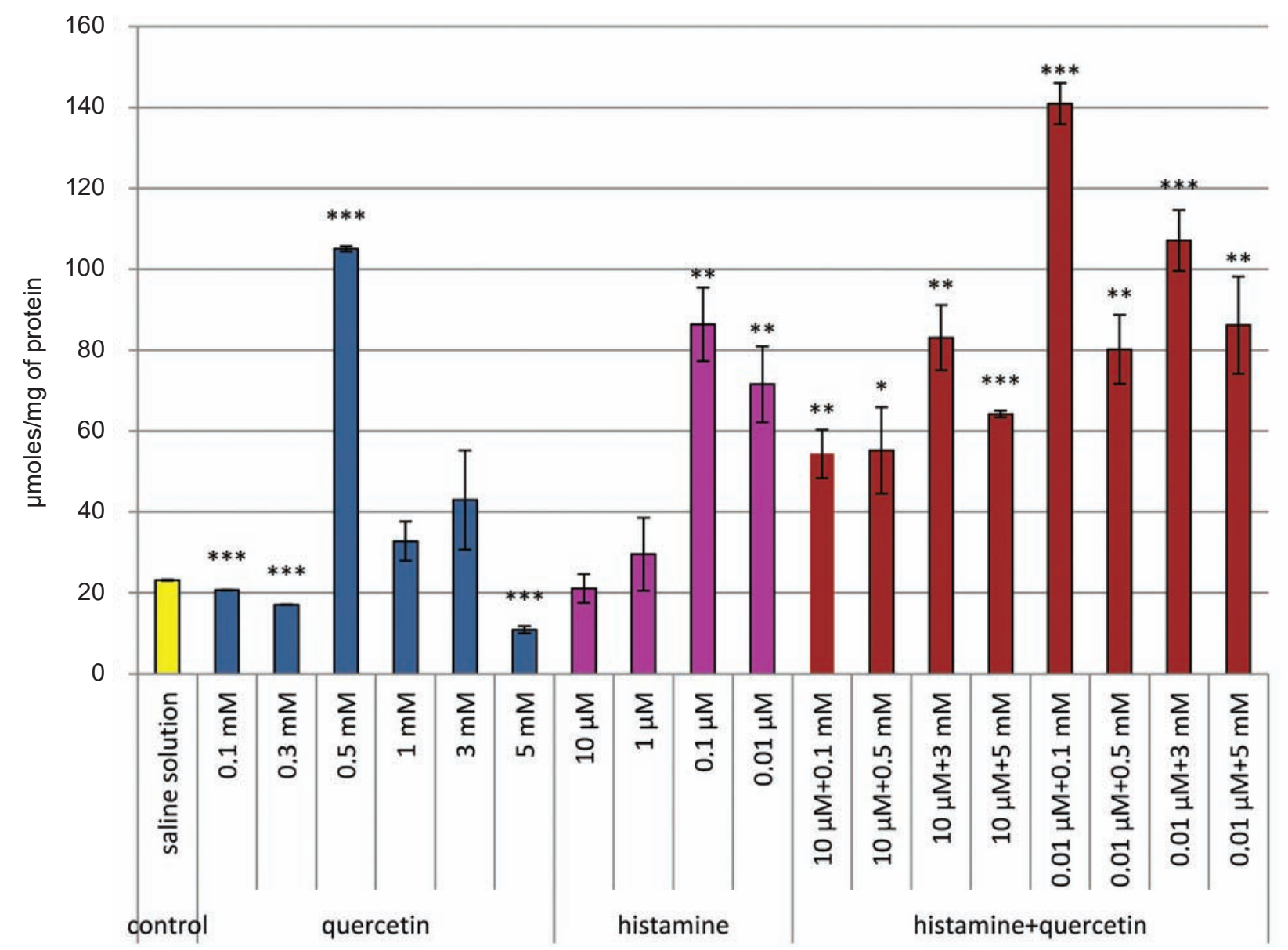

Fig. 3. The content of the carbonyl groups of neutralin character proteins in rat erythrocyte haemolysates under the action of quercetin, histamine and the combination of histamine and quercetin ( ${ }^{*} P \geq 0.95 ; * * P \geq 0.99$; $* * * P \geq 0.999)$

against the background of quercetin, produces a more pronounced intensification of oxidative modification of proteins, compared to higher. Histamine may be able to react with quercetin, resulting in the formation of harmful metabolites that damage erythrocyte proteins.

We also determined the content of carbonyl groups of proteins of basic character. The content of carbonyl groups of proteins of the basic character, as well as the content of carbonyl groups of proteins of neutral character, decreased in 1.5 times by the action of saline solution. ( $P \geq 0.999)$. Under these conditions, control was considered the experimental group with the addition of saline. Quercetin at 0.1; 0.3; $5 \mathrm{mM}$ concentrations caused a decrease of the content of carbonyl groups of basic proteins in erythrocytes by $29 \%, 41 \%, 50 \%$, respectively, was found. Whereas bioflavonoid $(0.5 \mathrm{mM})$ caused increase this content (by 119\%; Fig. 4). It noted that the tendency of changes in the content of carbonyl groups of pro- teins of basic character is the same as that carbonyl groups of proteins of neutral character (Fig. 3).

Addition to the blood of rats of histamine at 0.1 and $0.01 \mu \mathrm{M}$ concentrations caused the intensification of oxidative modification of proteins (the formation of carbonyl groups of both basic and neutral character) in erythrocytes (Figs. 3, 4).

The action of combination histamine and quercetin increased the content of carbonyl groups of proteins of the basic character (Fig. 4). Thus, the most intensive increase in the content of the studied indicator detected by the action a combination of the histamine at $0.01 \mu \mathrm{m}$ concentration and quercetin at $0.1 ; 3 ; 5 \mathrm{mM}$ concentrations (increase by $220 \%$, $190 \%$, 215\%, respectively). Therefore, we assume that histamine, quercetin, and its combination have the same effect on the accumulation of carbonyl groups of proteins of the basic character and neutral character in the red blood cells of rats. 


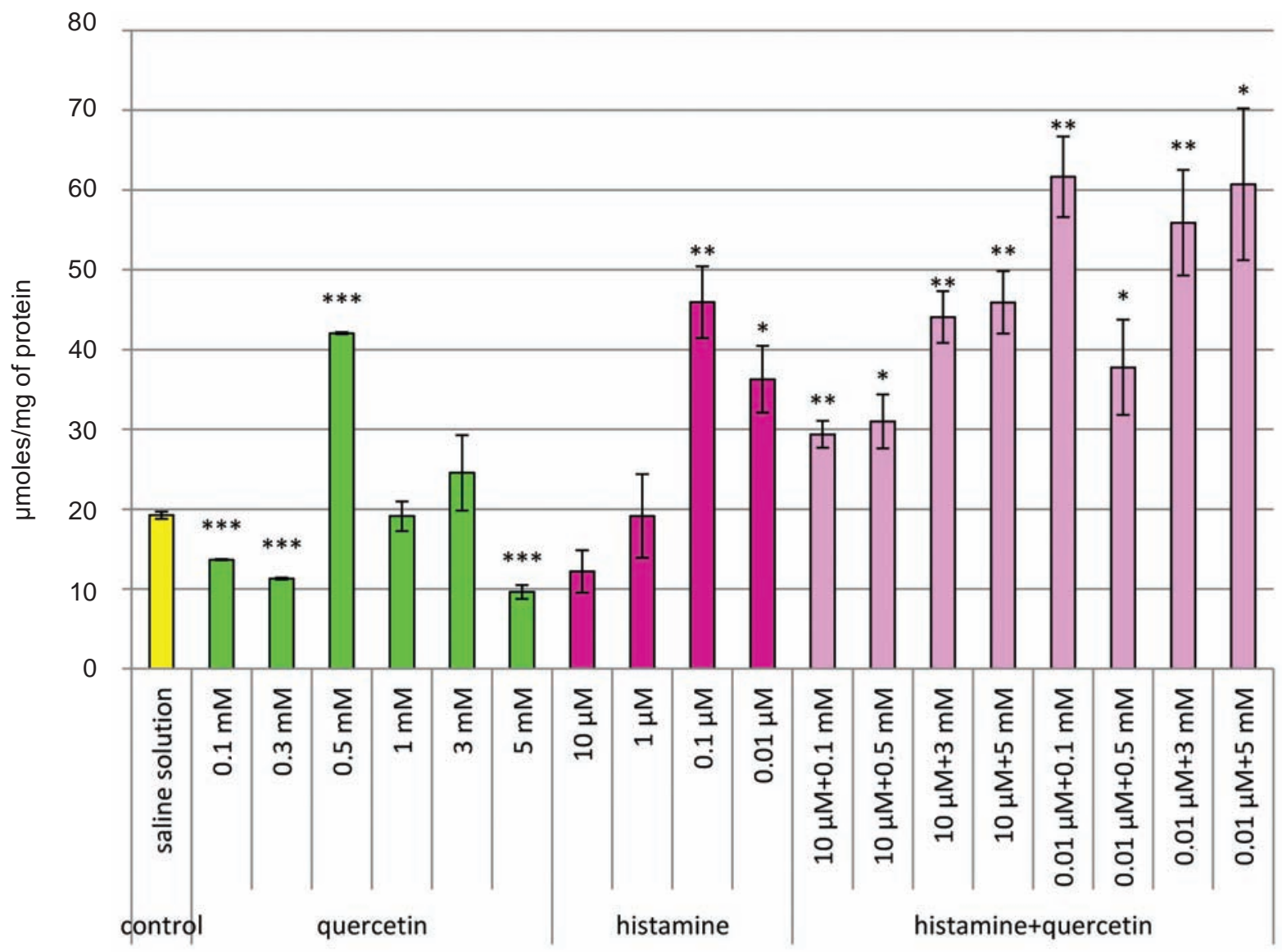

Fig. 4. The content of the carbonyl groups of main character proteins in rat erythrocyte haemolysates under the action of quercetin, histamine and the combined effects of histamine and quercetin $(* P \geq 0.95 ; * * P \geq 0.99$; $* * * P \geq 0.999)$

Thus, quercetin in all studied concentrations caused a decrease in the content of lipid hydroperoxides. The same effect is, relative to the content of carbonyl groups of proteins, caused by quercetin in the concentration of $0.1 ; 0.3 ; 5 \mathrm{mM}$. Quercetin at the concentration of $0.5 \mathrm{mM}$ caused an increase in the content of carbonyl groups of proteins and in the concentration of $5 \mathrm{mM}$ caused a decrease in the content of TBA-active products in rat erythrocytes in vitro. Histamine slowed down the intensity of lipid peroxidation processes in erythrocyte hemolysate. Histamine at 0.1 and $0.01 \mu \mathrm{M}$ concentration caused an intensification of oxidative protein modification in rat erythrocytes. The simultaneous addition of histamine and quercetin to the blood caused an increase in the intensity of lipoperoxidation processes, except for combinations of concentrations: $0.01 \mu \mathrm{M}$ histamine and 3 and $5 \mathrm{mM}$ quercetin, in which the content of these products decreases. The combined effect of quercetin and histamine caused a significant increase in the content of carbonyl groups of proteins in rat erythrocytes.

Conflict of interest. Authors have completed the Unified Conflicts of Interest form at http://ukrbiochemjournal.org/wp-content/uploads/2018/12/ coi_disclosure.pdf and declare no conflict of interest.

Funding. This research was conducted as part of the scientific projects "Oxidant-antioxidant homeostasis and membrane transport systems of bioobjects under the action of physicochemical factors" (№ state registration 0116U001633, 2016-2018. Supervisor - prof. D. I. Sanahursky), "Membrane-related processes in cold-blooded and warm-blooded under pathological conditions and the action of physicochemical factors" (№ state registration 0119U002323, 2019-2021. Supervisor - prof. A. M. Babsky). 


\section{ВІЛЬНОРАДИКАЛЬНІ РЕАКЦІЇ В ЕРИТРОЦИТАХ КРОВІ ЩУРІВ ЗА ДIÏ КВЕРЦЕТИНУ І ГІСТАМІНУ}

\author{
Н. П. Гарасим ${ }^{\bowtie}$, М. Я. Буклів, А. Р. Зинь, \\ С. М. Мандзинеичь, А. О. Безкоровайний, \\ Д. І. Санагурський
}

Львівський національний університет імені Івана Франка, біологічний факультет, кафедра біофізики та біоінформатики;

凶e-mail: garasymnataly@gmail.com

Метою роботи було оцінити in vitro вплив кверцетину та гістаміну окремо або в поєднанні на вільнорадикальний стан еритроцитів щурів. Кверцетин $(0,1 ; 0,5 ; 3,0 ; 5,0$ мМ) та гістамін $(0,01$ та 10,0 мкМ) додавали до цільної крові окремо або разом. Визначали у гемолізованих еритроцитах вміст гідропероксидів, ТБА-активних продуктів та карбонільних груп протеїнів. Найбільший вплив на показники стану еритроцитів, який виявлявся в істотному підвищенні рівня ТБАактивних продуктів та вмісту карбонільних груп протеїнів встановлено за поєднаної дії кверцетину та гістаміну.

К л ю ч о в і с с о в а: гістамін, кверцетин, еритроцити, пероксидне окислення ліпідів, карбонільні групи протеїнів.

\section{References}

1. Demkovych A. Effects of flavonol quercetin on activity of lipid peroxide oxidation in experimental bacterial-immune periodontitis. Interv Med Appl Sci. 2019; 11(1): 55-59.

2. Niki E. Oxidant-specific biomarkers of oxidative stress. Association with atherosclerosis and implication for antioxidant effects. Free Radic Biol Med. 2018; 120: 425-440.

3. Buddi R, Lin B, Atilan SR, Zorapapel NC, Kenney MC, Brown DJ. Evidence of oxidative stress in human corneal diseases. J Histochem Cytochem. 2002; 50(3): 341-351.

4. Marunaka Y, Marunaka R, Sun H, Yamamoto T, Kanamura N, Inui T, Taruno A. Actions of quercetin, a polyphenol, on blood pressure. Molecules. 2017; 22(2): 209.

5. Suganthy N, Devi KP, Nabavi SF, Braidy N, Nabavi SM. Bioactive effects of quercetin in the central nervous system: Focusing on the mechanisms of actions. Biomed Pharmacother. 2016; 84: 892-908.

6. Andres S, Pevny S, Ziegenhagen R, Bakhiya N, Schäfer B, Hirsch-Ernst KI, Lampen A. Safety Aspects of the Use of Quercetin as a Dietary
Supplement. Mol Nutr Food Res. 2018; 62(1): 1700447.

7. Duranti G, Ceci R, Patrizio F, Sgrò P, Di Luigi L, Sabatini S, Felici F, Bazzucchi I. Chronic consumption of quercetin reduces erythrocytes oxidative damage: Evaluation at resting and after eccentric exercise in humans. Nutr Res. 2018; 50: 73-81.

8. Lieberman P. The basics of histamine biology. Ann Allergy Asthma Immunol. 2011; 106(2 Suppl): S2-S5.

9. Gurgen SG, Erdogan D, Take-Kaplanoglu G. The effect of histamine on kidney by fasting in rats. Bratisl Lek Listy. 2013; 114(5): 251-257.

10. Chumakova SP, Urazova OI, Zyma AP, Novitskiy VV. Features of the physiology of erythrocytes. Hemolysis and eryptosis. Russ J Hematol Transfusiol. 2018; 63(4): 343-351. (In Russian).

11. Zervas E, Loukides S, Papatheodorou G, Psathakis K, Tsindiris K, Panagou P, Kalogeropoulos N. Magnesium levels in plasma and erythrocytes before and after histamine challenge. Eur Respir J. 2000; 16(4): 621-625.

12. Helms CC, Gladwin MT, Kim-Shapiro DB. Erythrocytes and Vascular Function: Oxygen and Nitric Oxide. Front Physiol. 2018; 9: 125.

13. Oleksiuk NP, Yanovych VG. The activity of pro- and antioxidant systems in the liver of freshwater fishes during different seasons. Ukr Biokhim Zhurn. 2010 82(3): 41-48. (In Ukrainian).

14. Timirbulatov RA, Seleznev EI. Method for increasing the intensity of free radical oxidation of lipid-containing components of the blood and its diagnostic significance. Lab Delo. 1981; (4): 209-211. (In Russian).

15. Meschyshyn IF, Poloviy VP Mechanism of oxidative modification of proteins. Buk Med Herald J. 1999; 1: 196-205. (In Ukrainian).

16. Lowry OH, Rosebrough NJ, Farr AL, Randall RJ. Protein measurement with the Folin phenol reagent. J Biol Chem. 1951; 193(1): 265-275.

17. Rogovsky VS, Matyushin AI, Shimanovsky NL. The prospects of Quercetinum and its derivatives administration for prevention and treatment of atherosclerosis. Int Med J. 2011; (3): 114-118. (In Russian).

18. Golovchak NP, Tarnovskaya AV, Kotsyumbas GI, Sanagursky DI Processes of lipid peroxidation in living organisms. Lviv: Ivan Franko National University of Lviv, 2012. 250 p. (In Ukrainian).

19. Ivasivka RS, Myronenko II. Influence of the quercetine on the dynamics IL-4, general IgE and cortisol as markers of the inflammation respiratory tract activity at bronchial asthma. Exp Clin Physiol Biochem. 2011; (2): 99-103. (In Ukrainian).

20. Fadeyeva HA. The role of mediators of inflammation and atopy in burdening of bronchial asthma course, associated with visceral obesity. Visnyk Sumy State Univy. Med Ser. 2009; 1(2): 162-167. (In Ukrainian). 